\title{
Maggie and Me
}

\section{George Moorse}

My father was Oak Waters, the stuttering auctioneer. He didn't make much of a living at auctioneering, handicapped the way he was, but I think that's why he chose his profession. The less you work, the more time you have to speculate upon the nature of the universe and of man in this world, that was his idea. $\mathrm{He}$ wrote a pamphlet called The Pyramid Theory of the Universe with his own diagrams and had it printed. He used to try to sell it at auctions, but most of the time ended up giving copies away. Unfortunately, not too many people thought that a pamphlet on cosmic law written by a stuttering auctioneer was worth reading. Things like that didn't bother Oak, though.

"There have been three ages of man," he said, "and out of them the Cosmic Pyramid was made. There was the Age of the Senses that ended with the invention of the wheel. Then there was the Age of the Dream, and that one ended with the Crucifixion. Now we're in the Age of Worry, and the sooner it ends, the better."

We lived in a quonset hut about a mile and a half up in the woods, behind the Ellmont lumberyard. Oak had a wife at the time I'm talking about. Her name was Eileen. She had never lived in a real house in her life. She was brought up in a trailer camp. Wood or stone walls made her nervous. That's why she loved the quonset hut and wouldn't have moved out if Oak had suddenly struck it rich auctioneering and bought a twenty-eight-thousand-dollar ranch house with a picture window and a painting of zebras eating flowers on the living room wall. Eileen was skinny and had freckles all over. She always kept a loaded shotgun within reach and could never remember to close the marmalade.

"Close that marmalade, woman," Oak said. "A person coming up here and looking through the window would think the place was haunted and wouldn't know what he could do under God to save himself from the ghosts."

Eileen rarely listened to what Oak had to say, but this time she asked him, "What has an open marmalade jar got to do with ghosts?"

"Well, if human beings lived in a place like this, they'd have to be some kind 
of otherworldly creatures would leave a pretty jar like that open for the flies and rice and $\mathrm{m}$-m-mats."

Usually he didn't stutter except when he was working, but I guess the idea of the ghosts got him upset. Eileen took her shotgun down and pointed it at the marmalade jar.

"I'm gonna shoot that marmalade right through the wall if you say one more word about it, Oak," she said.

"G-g-go ahead," Oak laughed.

Eileen didn't even aim. She shot right from the hip with both barrels at once. The marmalade jar just disintegrated and moved on with the blast, traveling through the tin wall of the hut and vanishing into the woods. My brother Tom and I were standing there in the kitchen when it happened.

"You seen it, boys," my father said. "She shot the marmalade and the wall, and she's got to be punished. Eileen, do you hear?"

"I'm not sorry I did it," Eileen said.

"I don't care how you feel," my father said, "a deed done again this hut is a a deed against the peace and good will of all men. In the back of my mind I've got a punishment I've been saving for such an occasion."

My brother and I got all frantic, thinking something violent was going to happen.

"There's a girl works down in the lumberyard," Oak said. "Her name is Heather Brayshaw and she's one of the fattest nicest young ladies I've ever met. Well, tomorrow at three o'clock when she takes her coffee break I'm going to go down there and ask her if she won't come up here and make sure the marmalade jars are tightly closed. And I want you two ladies to like each other, Eileen, or I'll be so unhappy under God that I won't know what to do."

Eileen put her shotgun on the kitchen table and sat down in a chair and crossed her legs.

"As long as I don't have to worry about the marmalade jars," Eileen said, "you can move a herd of wild Indians in here. Right boys?"

"Right, Eileen," we said. I was thinking it would be pretty great if some wild Indians moved in, but I didn't really like the idea of Miss Heather Brayshaw of the lumberyard. I knew her, and so did Tom. She was the fat one who worked the adding machine. Every time we went into town without Eileen, Oak would stop by and flirt with her through the open window. There was a nice smell of fresh wood in the air, and the blood-curdling sound of saws, and lumber to play in, so we usually didn't take much notice of Heather Brayshaw.

"Boys, run out and get some tar paper and fix that hole in the wall," my father said. Then he went over to Eileen and kissed her ear and squinched her breasts a little.

There was some tar paper in the back of the pickup truck. My brother and I went out to get it. (We used that pickup truck in the summer to carry watermelons in. Eileen would put on a pair of riding boots and sit in the back of the truck among the watermelons until we got to a likely spot on the road. Then she'd hammer on the panels and we would stop. Eileen would put up a "Fresh Water- 
mellon" sign and sit in the open back of the truck, her legs up and her riding boots showing. My brother and I used to help her sell melons. Sometimes we'd gather walnuts or steal stuff from the farmers, but most of the time we really would work.)

We hauled the tar paper out of the back of the truck and spent the rest of the day fixing up the wall of the quonset hut while Oak and Eileen made love and the radio played Al Martino and Doris Day and Percy Faith and Perry Como and Fats Domino and the Everly Brothers and down below in the valley the saws of the lumber yard said "ya-waaah, ya-waaah, ya-waaah!"

Next afternoon Oak went down to Ellmont and on the weekend Heather Brayshaw moved into the quonset hut. Oak got out his Kodak camera and took a picture of all of us together on the first day. Tom and I made awful faces, I even stuck two fingers in one nostril just as the camera clicked. Eileen came out to meet Heather and Oak with a topless marmalade jar in her hand, and that is in the photograph, too. There we all are, looking a little bit slanted in front of the blackened corrugated walls of the hut-Oak and Eileen and Heather and Tom and Abraham the dog and Jeffings Brine the cat. To the right there's last year's Christmas tree with some bits of tinsel still on it, reclining in a mud puddle. To the left is an old bicycle frame, a broken stove, a headless plaster statue of Jesus, some tin cans and in the distance the pickup truck.

"Well," said Oak, lowering the Kodak, "that's it. Now let's all get into the truck and drive down to Garson Lake and steal some chickens."

Garson Lake is supposed to be the deepest inland body of water in the United States. You can drop two miles of weighted fishing line into it without hitting bottom. I almost drowned in it once in a very humiliating way. There is a little grassless knoll above the lake and I was sitting on my bicycle at the top of this knoll, watching some sunfish in the water, when I started to roll straight down and couldn't stop. You see I didn't have my feet on the pedals. Bump. bump, I crashed right into the water. The bike kept rolling, with me on it. There were some fishermen on the bank and they started to laugh like hell.

"Write a letter from the bottom, Joel"

"Hey Joe, there's supposed to be an Indian princess down there! Let us know if you taste any of the ole dark meat, heh heh!"

Somehow I got out, but my poor bicycle kept on rolling, under water, and vanished into the murk.

"Joe, you got a wet ass!" the fishermen roared.

I had to walk home. It rained, and I told everybody that my bike got stolen by some tough kids from East Alba, so the incident was my secret until one of the fishermen told Oak about it. By that time I had built a new bicycle out of spare parts and every time Oak sent me somewhere on it he would say, "Joe, get in your boat and sail down to Ellmont and get a few cans of beer."

Well, we drove down to Garson Lake to steal chickens, Oak and Heather in the front of the pickup truck, Eileen and Tom and I in the back. Without know- 
ing it, I was approaching what would be a turning point for me, that is, Maggie. But instead of thinking about the future implications of the ride, I was banging on the hollow panels of the truck and singing "The Green Grass Grows All Around" along with everybody else.

Down in Garson Lake we took a back road and came to a house that had been abandoned for about three days by the look of things. The doors were freshly boarded up and there were empty milk bottles on the porch. The house was dark and dirty. We all peered out at it.

"St-st-st-stealing isn't the right word for what we're abou-about to do," Oak said, a little bit excited. "W-we're s-s-s-simply t-taking what b-belongs to us u-under G-g," he closed his eyes for a moment, "G-God."

We all got out of the truck.

"I see one," Heather said.

She pointed to the back yard. There was a pile of orange crates and old screen windows back there, and on top of the pile stood a chicken.

"I see one," Tom said.

He pointed too. There was another chicken on the garage roof.

Without another word we all ran round in back of the house and started chasing chickens. The hen that had been on top of the woodpile let out a squawk and sped around the house, and I followed her. Tom was throwing stones at the one on the garage roof. Eileen had discovered another one in rhubarb patch and was stalking it, her hands out stiff in front of her like a vampire.

In back of the house there was garbage and old chicken wire everywhere, and it was hard to run. The chicken darted into a mess of honeysuckle and I stumbled after it. As I ran into the bushes, a quiet lady and a beautiful girl appeared from behind an overgrown hedge. The beautiful girl and I looked at each other and started smiling and laughing. For a moment I forgot my chicken and just stood there. I'd never seen such a soft, sensual, alert, aware, determined, happy girl in my life. Our glances couldn't unlock. She and the quiet lady stood there, motionless. Finally I bolted and ran on past them and down along the lakeside throwing stones at the chicken to try to corner it by the water.

I picked up a big branch and used it as a net. In about twenty minutes I came up to the house again with the chicken, warm and kicking, in my arms.

Eileen had caught her chicken, too. Tom's had got away. Heather was sitting in the truck, soaked with sweat and panting like a dog. Oak hadn't even tried to chase a chicken. He was leaning against the dirty shingles of the house, his arm around the quiet lady I had met by the honeysuckle. Tom and the beautiful girl were playing with the chickens in an orange-crate.

"This here is Mrs. Miller, Joe," said Oak. "We just met but it is love at first sight. She and her little daughter Maggie are coming to live with us in the quonset."

I didn't say anything. I just glanced at Heather. So did Eileen, but she was laughing.

"Don't worry, Joe, worry is a disease of time, and time a disease of space. Just say hello and let me take care of sleeping arrangements." 
“Hello," I said.

"Hi Joe," Mrs. Miller said.

"How do you do," said Maggie. Then she turned to Tom and continued to play with the chickens.

I didn't know what to do, so I stood around laughing and picking my nose until we went back to the hut.

About two years later we had a big corn dinner on the night of the heavyweight championship fight. Tom and I had gotten used to Mrs. Miller and Maggie right away, and so had Eileen, but Heather never had. Even now she was full of nasty remarks whenever she had to do anything together with Millie. We called Mrs. Miller Millie right from the start. I believe she didn't have a first name. Oak had given up involving himself in any disputes among the women, as he had given up auctioneering. He wasn't doing anything now but working on The Pyramid Theory of the Universe, Part II.

Heather and Millie carried the big pot of corn out in front of the quonset hut. Millie was quiet, but Heather was screaming and bitching and saying that Millie was doing everything wrong. Eileen stayed indoors at the stove, where she could be close to her shotgun.

It was a warm night, full of fireflies (which we called lightning bugs) and the smoke of cattails (which we called punks) burning to keep the mosquitoes away. The radio was on, the sports announcer was describing the great fight blow-forblow.

"That man ain't a nigger, he's a gorilla!" Oak said, biting into his corn. "He's got arms as long as his legs, and fists like catcher's mitts."

"To think that they got the right to vote," said Heather. She really looked fat as she sat there, eating two corns-on-the-cob at once.

My brother and I and Maggie looked at each other and sighed. It really got boring when Oak and the women started talking about niggers. They could do it for hours and days, and always said the same stupid things.

"Let's go catch lightning bugs," I said.

The three of us got jars and went off into the woods. Up there the air was swarming with fireflies. They were like rain burning, drifting up instead of down. One of them was in front of me in a bush, blinking faster than I had ever seen a firefly blink before. I reached out and grabbed him in the dark, and got a big handful of garden spider. The poor little bastard was being devoured by the spider and was trying to warn his friends.

I threw him into the jar anyway and looked around for Tom and Maggie to tell them about it. They weren't anywhere to be seen. I couldn't hear them either. The forest was full of the peep of tree frogs and the chirp of crickets. From the quonset hut came the noise of the radio, and odd drunken words about niggers. Oak let out a big laugh. An airplane flew over.

"Tom! Maggie!" Nobody answered.

I always hated to be left alone, but this was awful.

"Tom! Maggie!"

Another firefly blinked right in front of my nose and I reached out and caught 
it wrong. It flattened in my fist. When I opened my hand there was glow-juice all over my palm. It luminesced for a moment, then faded away.

Tom had been saying for a few months that Maggie was his girlfriend, but I never quite believed him. I always figured that Maggie secretly loved me, because of the way she had smiled at me the first time we met. I must have thought about that meeting and the honeysuckle and the chickens every hour every day since she came to live with us.

Tom was tough. He didn't think about such things. He probably never noticed them. He just said, "Maggie's my girl," and that was it.

Well he was right. That was it. Maggie believed it, too.

I caught a few more fireflies and then went back to the quonset hut. Eileen had come out of the house and was smoking a cigarette. Oak and Millie and Heather had stopped talking about niggers and were listening to the fight. The sixth round was just beginning.

"Eat some more corn, Joe," Eileen said.

I put the jar of fireflies down on the ground and got myself another piece of corn. I put some salt and butter on it and sat there eating. Up above another jet passed. Its lights blinked red and green through the yellow of the fireflies.

"Where's Maggie and Tom?" I asked.

Eileen took a long drag on her Camel, coughed a couple of times and smiled at me.

"Well Joe, they're fourteen years old," she said. "I'd venture they're somewhere off in the woods, spilling the old milk, if you know what I mean."

"The rats!" I said.

"No boy," Eileen said. “That ain't vermin, that's human. Maggie will be around for awhile. Just wait. You'll get your turn."

I started to cry. Then I got so confused that I went over and ate up all the leftover corn, and had a stomach ache for three days.

The confusion in my mind started as a trickle, but pretty soon it turned into a river and then into an ocean and I was adrift in it. I kept on getting more and more confused the older I became. The more confused I got, the more I loved Maggie, and the more Maggie loved Tom. When a year passed and I had not yet had my turn to spill the old milk, as Eileen said, I began to blame everybody but myself for it, especially Eileen. I began to hate her, as a matter of fact.

"What's eating you, Joe," she'd say at first, and I would growl at her. Eventually we simply growled at each other. Eileen had no idea what she had done, and didn't understand why I had stopped liking her.

One day she left.

Oak came into the quonset hut and immediately noticed something was wrong. But he didn't realize it was the absence of Eileen's shotgun that was upsetting him. He thought maybe the food stamps had been devoured by rats. For awhile he stood there in the kitchen, looking at the empty shelf. Then it came to him.

"Holy God to Jesus Almighty, Eileen's gonel" 
I knew it was my fault, but I was too confused to say anything about it.

A few weeks later we moved out of the quonset hut into town. Oak couldn't stand the hut without Eileen, though he couldn't admit this to Millie or Heather. He just said that since we were going to high school we ought to be closer to it and that he had already found a place.

Nobody argued. I guess Millie and Heather were glad to get off the mountain and into town. They didn't miss Eileen, either, and never mentioned her name again. She never wrote. I wonder what became of her.

The place in town was a three-room apartment above the drugstore. It had high tin ceilings that made us feel right at home. The floors were covered with orange linoleum and the walls with peeling 1920's wallpaper. The place gave you the impression of a cage abandoned by some kind of giant insect. In the summer it was unbearably hot and in the winter too cold to ever be comfortable in. The toilet was the biggest room in the apartment. When I started writing music I put a second-hand electric piano in there. It was quiet since it faced the back lot, but there was a blue jay nest in the tree by the window and the birds sometimes made a lot of racket. I used to compose in there as soon as I got home from school. Whenever somebody had to use the toilet I left, and stood outside in the hall, humming the song I was working on.

"Don't stand so close to the door," Maggie used to say. "I don't want you listening while I'm using the toilet."

"I'm not listening," I would say. "I'm humming a song I'm writing."

"What's it called?"

"Love and Death."

"You call that a song title?"

"Well, it's more like a concerto or something. It has no words."

"Boy, you're really going nuts. You've got bats in your belfry, Joe, you know that?"

"How come you don't love me, Maggie?"

"I love Tom, you know that, Joe. Now go down the hall a ways and stop listening when I'm on the toilet. It makes me nervous and I can't go."

Around that time I started composing some of the songs I later sold, and some that I performed on my record. A couple of them have never been finished, but I haven't given up on them. I'll work on a song for ten years until I feel that it's just right. I never throw one away.

It was summertime again, the second one in the apartment, when my confusion reached its peak. Things always seem to happen to me in the summertime. All the awful things and the good ones too.

Tom was working as a truck driver then, crossing half the United States every week, and only coming home about twice a month. Maggie was lonely, but she didn't mess with other boys.

Maggie was slim now and had a lot of reddish-brown hair with natural curls in it. She had very large green eyes and high cheekbones and a widish face. She was very beautiful. The woman upstairs above the apartment, who got up every 
morning at seven and played "Little Red Rooster" at top volume, thought Maggie was a famous actress and always invited her up for coffee.

Tom was due back from his truck driving the next day. It was the hottest night in human memory. Down the valley there was a forest fire. I wondered if our old quonset hut would vanish in it. Oak and Millie and Heather were in the front room, playing cards, drinking beer and watching television. Maggie and I went out on the porch roof. I rolled a joint and we sat there on the hot tar paper, smoking and looking at the red sky. The fire looked like anybody's dream of Hell in the distance. We could smell it. Sometimes sparks flew into the town.

"I've always loved you, Maggie," I said.

"My God, Joe," Maggie said.

Mini-skirts were in fashion and she was wearing the shortest one in town. Her knees were up around my left eye. I lay back on the room and sucked at the joint and swallowed the smoke.

"Hey you fellers," Oak said at the window. He leaned out in his undershirt. He had his hand of cards fanned out in front of him. "Give me a puff of that joint," he said. "You wouldn't cheat an old fart, would you?"

I handed the joint across to Oak and hoped that he would go away soon. Every time he smoked grass he started talking about The Pyramid Theory o the Universe. It was horrible.

"Why don't you go down and finish your card game, pop?" I said.

Oak almost swallowed the joint. Then he handed it over to Maggie and hung there in the window, his eyes spreading like spilled ink and his face turning purple, until he exhaled. Then he turned laughing and vanished.

"He's getting senile," Maggie said.

"Yep," I said.

Down the valley the fire looked like a gigantic red corkscrew, reaching up toward the stars. The smell of wood smoke became heavier.

"One day this whole country is going to burn up," Maggie said. "I saw it in my dreams."

"And you say I'm crazy."

"You're all right, Joe," she said.

We lay there a while longer; then he got up and climbed back through the window.

"I'm going to bed," she said.

"Good night, Maggie."

"Good night, Joe."

I rolled myself another joint and smoked the whole thing alone. In about an hour I was so stoned I was seeing things, so out of my mind that I was hearing whole symphonies. I thought about going into the toilet and trying to play them on my electric piano, so I slipped inside and went down the hall. Maggie's door was half open because of the heat. Instead of going to my piano I went in there. Maggie was asleep. She was naked and the sheet were knotted up around her feet.

I sat down on the bed. 
“Maggie?” I said.

She opened her eyes.

"Joe?" she said. "Come here."

I was so sure that she was going to kick me out that I had already begun to stand up when she spoke. Now I stood up all the way and undressed. It was about the most confusing moment of my life!

Maggie took me in her arms and we made love for a long time. I knew she knew it was me and not Tom, because she kept saying, "Joe, Joe, Joe!"

Then we lay there, covered with perspiration. The television was still on down the hall. Out in the street fire engines were passing.

Suddenly the door opened all the way and Oak walked into the room. He came over and sat down on the chair beside the bed. I figured there was nothing to do about it but just lie there.

"Tom's dead," he said. "They just came u-up with the m-message. An a-a-accident. In Ohio."

Maggie began to cry, to hug me and to hit me at the same time.

“Tom's d-d-dead!" Oak said.

He got up and walked out of the room. For a moment he stood in the light of the hall and I noticed that the cards were still in his hand.

"I hate you, Joe," Maggie said.

Ten days later I moved to San Francisco.

There's a little park there off Taylor Street, up on the hill where the streets fork and dive down to the ocean and Pacific Heights. It is a perfect island of a park. It's concave and faces all the tall downtown office buildings. The trolley cars pass below and you can hear them moving along, making bell- and tracksounds as they go. I guess you can hear every typewriter in San Francisco from that park. But somehow it seems quiet, and there's a nice smell like fried noodles in the air.

I think I'm the only one who ever discovered that park because I went there every day and every day I was alone.

At first I carried a notebook and pencil with me and wrote my music that way. Then one day I was in a music store and discovered a kind of pocket electric organ called a Stylophone. I bought it for seventeen dollars and after that I always sat on my bench, making real music in San Francisco.

I wrote a song there called "Sometimes You Can See the Oakland Bridge," because sometimes you could.

Even when it rained I sat in the park making up songs. I invented a way of propping an umbrella up behind me on the bench. For some reason that umbrella hanging over my head made me feel like a Tibetan monk, and I began to compose oriental melodies.

One day a girl came and sat down next to me on the bench and squeezed in under the umbrella. Her hair was stringy and yellow. She had a pointed nose and wore big round pink-tinted glasses, a long skirt and a floppy hat. 
"Man are you weird," she said.

"Would you mind?" I said. "Don't bother me, please."

"Aw," she said. "Don't be so uptight. You're a composer, huh?"

"Yep," I said.

"Far out! How come you don't play with a rock band?"

"Come on," I said.

"I thought you were hip."

"What's your name?"

"Betty."

I got up. The umbrella rose with me.

"You want to have some rum-raisin ice cream?" I said.

"Rum-raisin ice cream?" Betty said, staying under the umbrella.

"Outta sight!"

We got stoned and had some ice cream and a couple of weeks later we moved to Garson Lake. When I say moving I mean we just moved us, because Betty didn't have anything but a rucksack with a few old dresses and some underwear and one book in it and I didn't have much besides my music and my Stylophone. We traveled cross country in a Volkswagen, following FM stations and Neil Young's voice all the way.

In Garson Lake I bought four old tourist cabins at an auction for ninety dollars apiece. I trucked them all over to a meadow beside the Kazanovy River and built a labyrinth of cinder-block foundations for them. I set them up like the four corners of a fort and connected them with passageways made of sewer piping. There was a courtyard-like space left over in the middle, so I got some of the Garson Lake hoodlums to help me and we built a thirty-eight-foot lookout tower in it. Betty and I painted dragons and mandalas and flaming bodhisattvas all over the tower, and hoisted a Don't Tread on Me flag on top.

When we were finished we wrote a letter to the governor declaring our independence from the state and the founding of the Rattlesnake Mantra Republic.

It didn't take long before Maggie showed up at the fort. Her hair had grown even longer since the last time I saw her. She was looking very beautiful, and she was pregnant.

"Welcome to the Rattlesnake Mantra Republic," I said.

Maggie came in and walked around the tower and inspected the four cabins. Betty and I slept in one of them. One of them was the kitchen. One of them was my composing room. Betty painted her pictures in the other one.

"Do you still love me, Joe?" Maggie asked.

"Well, I don't know, Maggie," I said. "Maybe I do and maybe I don't. Do you still hate me?"

"I don't think so," Maggie said.

"Well, you might as well move in then, Maggie," I said. "I can take my composing stuff up into the tower, and you can have the cabin. I guess you won't mind sharing it with the baby when it comes."

"It's your baby, Joe."

"That's all right, Maggie," I said. 
A couple of days later Oak showed up. He had aged a lot. Somehow or other he had caught a limp while I was gone. The way he walked, you'd think he'd always had it.

"Glad to see you back, Joe," my father said. "I read in the newspaper about you starting your own republic and I felt kind of sorry that you never called."

"I don't have a telephone, pop," I said.

"Well, never mind, boy," he said. "I brought along a couple of crates of The Pyramid Theory of the Universe. I thought you'd probably be getting a lot of visitors up here in your republic and you could get rid of a few copies for me now and then."

"Sure, pop," I said. "Just leave them in the tower. I guess I'll have to build an extra shed for them eventually, though."

"It's only a thousand copies, boy," Oak said.

"Want to have a look from the top of the tower?" I said.

"Nothing would please me better under God," Oak said.

We went up to the top of the tower and looked out over the lake. The falls where the Kazanovy empties into Garson Lake are about three hundred feet below the fort, but the strange thing is, you can't see them at all. The Kazanovy just seems to turn white and to end, then there's a patch of green and rocks and Garson Lake begins.

From the tower we could see Maggie driving an old red Chevrolet up toward the fort and getting out and carrying some cardboard boxes full of groceries inside.

"She hasn't been the same since your brother died," Oak said, watching her. "No?" I said.

"She has nightmares all the time and talks in her sleep," Oak said. "She's like a broken radio."

"What does she talk about?" I said. "Tom?"

"Hell no," the old man said. "She keeps screaming about chickens." 